\title{
SUPERELEMENT SIMULATION TECHNIQUE OF DYNAMICS FOR LARGE-SIZE SYSTEMS "BASE - REINFORCED CONCRETE STRUCTURES - METAL STRUCTURES”. VERIFICATION AND APPROBATION
}

\author{
Alexander I. Nagibovich \\ Scientific Research Center "StaDyO", Moscow, RUSSIA \\ National Research Moscow State University of Civil Engineering, Moscow, RUSSIA
}

\begin{abstract}
The distinctive paper presents short descriptions, verification and approbation of the developed technique of numerical (superelement) simulation of dynamics for large-size combined systems "base - reinforced concrete structures - metal structures".
\end{abstract}

Keywords: mathematical modeling, numerical methods, finite element method, superelement, component mode synthesis, stress-strain state, strain-stress state, dynamic characteristics, natural frequencies and modes, mechanical safety, large-size combined systems

\section{МЕТОДИКА СУПЕРЭЛЕМЕНТНОГО МОДЕЛИРОВАНИЯ ДИНАМИКИ БОЛЬШЕРАЗМЕРНЫХ СИСТЕМ «ОСНОВАНИЕ - ЖЕЛЕЗОБЕТОННЫЕ КОНСТРУКЦИИ - МЕТАЛЛИЧЕСКИЕ КОНСТРУКЦИИ». ВЕРИФИКАЦИЯ И АПРОБАЦИЯ}

\author{
А.И. Нагибович \\ Научно-исследовательский центр СтаДиО, г. Москва, РОССИЯ \\ Национальный исследовательский Московский государственный строительный университет, \\ г. Москва, РОССИЯ
}

\begin{abstract}
Аннотация: В настоящей статье представлены: краткое описание, верификация и апробация разработанной методики численного (суперэлеметного) моделирования динамики большеразмерных комбинированных систем «основание - железобетонные конструкции - металлические конструкции».
\end{abstract}

\footnotetext{
Ключевые слова: математическое моделирование, численные методы, метод конечных элементов, суперэлемент, метод динамического синтеза подконструкций, напряженно-деформированное состояние, динамические характеристики, собственные частоты и формы колебаний, механическая безопасность, большеразмерные комбинированные системы
}

\section{INTRODUCTION}

A key feature of the numerical simulation of the static and dynamic stress-strain state of unique construction objects: the development and optimization of related large-sized basic subsystems "base", "reinforced concrete structures", "metal structures of roof" are carried out independently various design organizations. The dimension of combined building systems can reach hundreds of thousands of different types of structural elements and, accordingly, tens of millions of degrees of freedom of their finite element models. It is not possible for such organizations to build an adequate computational model of a complete system, for example, modern football stadiums. Obstacles to this are various factors: from the incompatibility of file formats of computational models in various software systems and the large computational 
dimension of such models to commercial secrets.

To solve this problem, it is necessary to develop and apply "advanced" methods of numerical simulation, which make it possible to justify the possibility of switching to investigations within the framework of individual subsystem models (the "organizational" aspect) and reduce the computational dimension of the problem.

It is convenient to build such a technique on the basis of superelement approaches. The superelement method or the substructure method is a procedure in which a group of finite elements is combined into one element, presented in the form of a matrix.

A single-matrix element is called a superelement and can be used in the calculation as a finite element.

For problems of static, a variant of the superelement method is used - static condensation (Guyan reduction) [1]. For dynamic problems, methods of dynamic synthesis of substructures (component mode synthesis) are used. Their advantage is that they allow you to correctly simulate the behavior of the structure under dynamic influences, by taking into account the truncated sets of generalized coordinates of the natural modes defined for each substructure of the system under study. The component mode synthesis, in turn, are divided into methods of fixed [2, $3]$, free $[4,5]$, mixed [6] and loaded boundaries [7].

\section{DESCRIPTION OF THE TECHNIQUE}

The developed superelement technique of numerical simulation of the dynamics of the systems "base - reinforced concrete structures metal structures" is intended to determine the parameters of stress-strain state, strength, dynamics of these large-sized combined systems under the influence of various kinds of influences. The general block diagram of the technique is shown in Figure 1.

To realize the possibility of investigation the associated subsystems "base - reinforced concrete structures" and "metal structures", developed, as a rule, by various organizations, two ways are proposed. In the first case, comparing the dynamic characteristics of the complete system and subsystems, evaluate their mutual influence and thereby justify the possibility of switching to individual models (blocks 1-5). In the second, universal, case to use superelement technologies. With the superelement approach (blocks 6-14), each of the organizations develops a FE-model of its "own" subsystem (block 6), forms a superelement (SE) (blocks 8-11), which is a set of influence matrices. Further, the teams of investigators exchange these superelements and join "their" FE-model with a superelement developed and formed by colleagues (blocks 12). This ensures the transition from the study of the complete system to individual subsystems with the correct consideration of the dynamic characteristics of the subsystems developed by subcontractors.

The proposed methodology uses two versions of the dynamic synthesis method, which differ in the way of limiting the docking degrees of freedom - the fixed interface method and the free interface method. Docking degrees of freedom are called those by which the superelement is docked with the FE model of the subsystem or other superelements.

The technique is implemented on the basis of the ANSYS Mechanical software package and the author's own software development.

A more detailed description of the developed superelement technique is given in $[8,9]$.

\section{VERIFICATION OF THE TECHNIQUE}

To verify the developed technique, the following tasks were selected. The task from the original verification report of the ANSYS Mechanical was selected as the first verification example. In this test example, the dynamic characteristics of the tuning fork, obtained using a full FE-model and superelement models using various methods for taking into account the internal mode shapes of substructures, are determined and compared. 
Superelement Simulation Technique of Dynamics for Large-Size System "Base - Reinforced Concrete Structures Metal Structures". Verification and Approbation

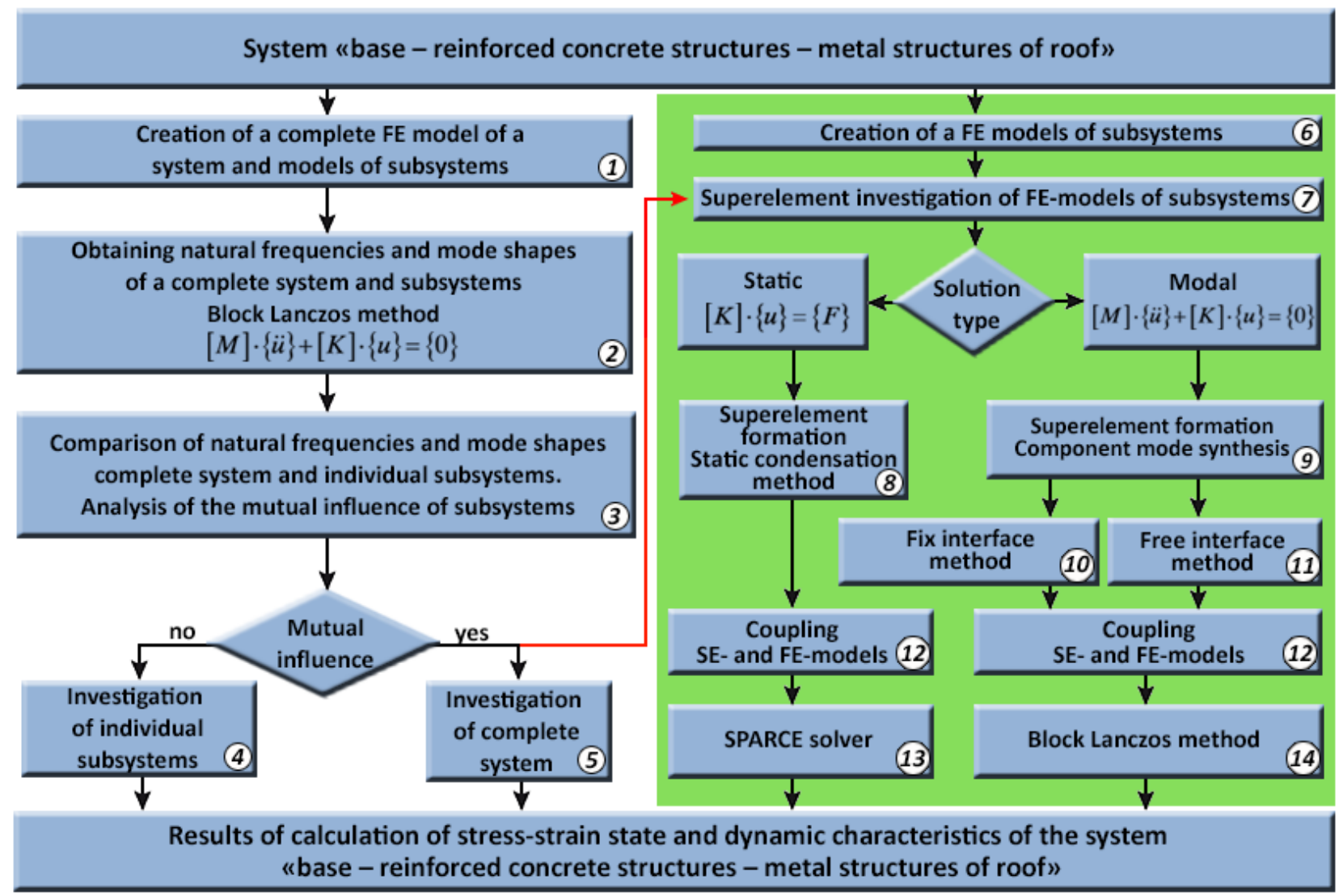

Figure 1. General block diagram of the developed technique of superelement simulation of dynamics of the systems "base - reinforced concrete structures - metal structures".

This example demonstrates the operability of the component mode synthesis of substructures. A comparative analysis of the obtained natural frequencies and mode shapes of the tuning fork for the mentioned models showed similar results for all the investigation options. The maximum difference between the obtained natural frequencies was $0.014 \%$. The most effective and convenient, from the point of view of practical use and implementation in the PC used, have shown themselves to be fixed and free interface methods.

As a second example of pricing for a real object - the entrance block of the Volgamall shopping center in Volzhsky, having a design similar to the type investigated for large-sized systems. In this example, the analysis was carried out:

- the influence of the details of the FE-model (finite element mesh) on the accuracy of the obtained dynamic characteristics of the structure, as well as on the "machine" time spent on the obtaining;

- the possibility of transition to the investigation of the dynamic characteristics of subsystems within the framework of individual models "base - reinforced concrete structures" and "metal structures of the roof";

- the possibilities and features of the application of the component mode synthesis to the investigations of this kind of combined systems. The influence of the choice of the method of accounting for the internal mode shapes of the substructure and the number of internal frequencies and mode shapes of the substructure taken into account were analyzed.

- "organizational" and computational effectiveness of the proposed options developed by the superelement technique.

Comparison of the obtained natural frequencies and mode shapes of the entrance block of the Volgamall on FE models of various details showed that dividing the model by 3-4 finite el- 
ements into one structural element of the structure (span of a plate, beam, column corresponds to optimal results and computational dimensions), element of the truss cover).

A comparative analysis of the obtained dynamic characteristics of the complete system "base reinforced concrete structures - metal structures of the roof" and subsystems showed a significant effect of the compliance of the support subsystem on the behavior of the coating structure subsystem. This indicates the impossibility of conducting independent investigations of the subsystems "base - reinforced concrete structures" and "metal structures of the roof".

Comparison of the natural frequencies and mode shapes of a complete system modeled "head-on" by finite elements and subsystems with superelements (hereinafter, the subsystem with superelement for brevity denotes the complete system in which one of the subsystems is modeled by finite elements and the second is dynamic superelement) shows almost identical results. The difference in natural frequencies, taking into account a sufficient number of internal mode shapes of substructures for the fixed-interface method, was mainly no more than $0.007 \%$, and for individual mode shapes up to $0.295 \%$. For the free interface method, basically, no more than $0.005 \%$, and for individual mode shapes, up to $0.038 \%$.

The number of internal mode shapes of the substructures, which must be taken into account to obtain an adequate result, significantly depends on the stiff-bone and inertial characteristics of the construction itself. For constructions of the type under consideration, it is necessary to take into account the internal mode shapes of the substructure in the frequency range 1.5-2 times higher than the studied frequency range of the entire system $[9,10]$.

For the considered problem of "small" dimension (bearing in mind real unique structures), the factor of computational efficiency, as shown by a comparative analysis with full FE models, is expectedly not a strong point of the developed superelement technique.

Based on the presented and analyzed results of verification and computational studies, the ap- plicability of superelement methods to simulating the dynamic characteristics of the investigated combined large-sized systems is substantiated.

Verification of the developed superelement technique in more detail is given in $[8,9]$.

\section{APPROBATION OF THE TECHNIQUE}

To approbate the developed superelement technique as the research objects were selected designed and constructed for the 2018 World Cup 2018 are large-capacity stadiums $(45,000$ spectators): in Nizhny Novgorod and Rostov-onDon, as illustrative examples of all branches of the technique.

Spatial shell-beam finite element and superelement models of stadium structures were developed and verified (Tables 1 and 2). For foundation slabs, walls, ceilings, stairwells and elevator shafts, folds of stands, beams under the folds of stands, SHELL181 type shells were used. Beams and columns are modeled by beam FEs of the BEAM188 type. MPC184 - an element of kinematic restrictions, was used at the junction of columns and floor slabs. LINK180 is a spatial core element working in tension or compression. Piles are modeled with special FEs of COMBIN14 type. The SURF154 element is used to assign various load effects. MATRIX50 - Superelement.

To obtain a significant part of the spectrum of natural frequencies and oscillation forms, the direct block Lanczos method was used. The investigations were carried out taking into account the masses only from the dead weight of supporting structures. For each system and subsystem, the frequencies and modes of natural vibrations in the range from 0 to $6 \mathrm{~Hz}$ were obtained. In the investigations using superelements, the internal mode shapes of the substructure were taken into account using the methods of a fixed boundary and a free boundary. The number of internal mode shapes of the substructure varied. The internal natural frequencies falling into the intervals were taken into account: up to $3 \mathrm{~Hz}, 6 \mathrm{~Hz}, 9 \mathrm{~Hz}, 12 \mathrm{~Hz}$. 
Superelement Simulation Technique of Dynamics for Large-Size System "Base - Reinforced Concrete Structures Metal Structures". Verification and Approbation

Table 1. Developed FE-models of the stadium in Nizhny Novgorod.

\begin{tabular}{|c|c|c|c|c|c|}
\hline No. & $\begin{array}{c}\text { FE-models } \\
\text { of system / subsystem }\end{array}$ & Picture & $\begin{array}{l}\text { Number } \\
\text { of } \\
\text { nodes }\end{array}$ & $\begin{array}{l}\text { Number } \\
\text { of } \\
\text { elements }\end{array}$ & FE types \\
\hline 1.1 & $\begin{array}{c}\text { "base - reinforced concrete } \\
\text { construction of foundations and } \\
\text { stands - } \\
\text { metal structures of the roof" }\end{array}$ & & 633461 & 699383 & $\begin{array}{c}\text { SHELL181, } \\
\text { BEAM188, } \\
\text { MPC184, } \\
\text { SURF154, } \\
\text { LINK180, } \\
\text { COMBIN14 }\end{array}$ \\
\hline 1.2 & $\begin{array}{c}\text { "base - reinforced concrete } \\
\text { construction of foundations } \\
\text { and stands" }\end{array}$ & & 624127 & 684500 & $\begin{array}{c}\text { SHELL181, } \\
\text { BEAM188, } \\
\text { MPC184, } \\
\text { SURF154 } \\
\text { COMBIN14 }\end{array}$ \\
\hline 1.3 & "metal structures of the roof" & & 9728 & 15102 & $\begin{array}{l}\text { BEAM188, } \\
\text { MPC184, } \\
\text { SURF154, } \\
\text { LINK180 }\end{array}$ \\
\hline 1.4 & $\begin{array}{c}\text { "base - reinforced concrete } \\
\text { construction of foundations and } \\
\text { stands" }+ \\
\text { superelement of the roof }\end{array}$ & & 624127 & 684501 & $\begin{array}{l}\text { SHELL181, } \\
\text { BEAM188, } \\
\text { MPC184, } \\
\text { SURF154, } \\
\text { COMBIN14, } \\
\text { MATRIX50 }\end{array}$ \\
\hline 1.5 & $\begin{array}{l}\text { "metal structures } \\
\text { of the roof"'+ superelement } \\
\text { of of foundations and stands }\end{array}$ & & 9728 & 15103 & $\begin{array}{l}\text { BEAM188, } \\
\text { MPC184, } \\
\text { SURF154, } \\
\text { LINK180, } \\
\text { MATRIX50 }\end{array}$ \\
\hline
\end{tabular}

A comparative analysis of the natural frequencies and mode shapes of the complete system "base - reinforced concrete structures of foundations and stands - metal structures of the roof" and subsystems of the stadium in Nizhny Novgorod revealed a weak effect of the flexibility of the support subsystem on the dynamic characteristics of the coating structure subsystem, which allows us to justify study of the latter in a separate model. In turn, the subsystem "metal structures of the roof" does not have a significant effect on the behavior of the support subsystem "base - reinforced concrete construction of foundations and tribunes", which also gives reason to carry out studies of the isolated subsystem.

A similar comparison of the natural frequencies and mode shapes of the complete system and subsystems of the stadium in Rostov-on-Don showed a significant mutual influence of the reference subsystem and the subsystem of the coating structures on the dynamic characteristics. This indicates the impossibility of conducting independent calculations of subsystems without taking into account the stiffness and mass characteristics of all elements of the complete system.

In Tables 3 and 4, the natural frequency of the complete system and subsystems on which the mode shapes coincide are marked with a green background. The red background marks those frequencies of subsystems at which the mode shapes do not correspond to the mode shapes of the complete system or are absent. 
Table 2. Developed FE-models of the stadium in Rostov-on-Don.

\begin{tabular}{|c|c|c|c|c|c|}
\hline No. & $\begin{array}{c}\text { FE-models of } \\
\text { system/subsystem }\end{array}$ & Picture & $\begin{array}{l}\text { Number } \\
\text { of } \\
\text { nodes }\end{array}$ & $\begin{array}{l}\text { Number } \\
\text { of } \\
\text { elements }\end{array}$ & FE types \\
\hline 2.1 & $\begin{array}{c}\text { "base - reinforced concrete } \\
\text { construction of foundations and } \\
\text { stands - metal structures of the } \\
\text { roof" }\end{array}$ & & 621048 & 604358 & $\begin{array}{l}\text { SHELL181, } \\
\text { MPC184, } \\
\text { BEAM188, } \\
\text { SURF154, } \\
\text { LINK180, } \\
\text { COMBIN14 }\end{array}$ \\
\hline 2.2 & $\begin{array}{c}\text { "base - reinforced concrete } \\
\text { construction of foundations and } \\
\text { stands" }\end{array}$ & & 599417 & 589387 & $\begin{array}{c}\text { SHELL181 } \\
\text { BEAM188 } \\
\text { MPC184 } \\
\text { SURF154 } \\
\text { COMBIN14 }\end{array}$ \\
\hline 2.3 & $\begin{array}{l}\text { "metal structures of the north- } \\
\text { east wing of the coating" }\end{array}$ & & 9185 & 6304 & $\begin{array}{l}\text { BEAM188 } \\
\text { LINK180 } \\
\text { SURF154 }\end{array}$ \\
\hline 2.4 & $\begin{array}{l}\text { "metal structures of the south- } \\
\text { western wing of the roof" }\end{array}$ & & 12446 & 8667 & $\begin{array}{l}\text { BEAM188 } \\
\text { LINK180 } \\
\text { SURF154 }\end{array}$ \\
\hline 2.5 & $\begin{array}{c}\text { "base - reinforced concrete } \\
\text { construction of foundations and } \\
\text { stands" }+ \\
\text { superelement of the roof }\end{array}$ & & 599417 & 589388 & $\begin{array}{l}\text { SHELL181, } \\
\text { MPC184, } \\
\text { BEAM188, } \\
\text { SURF154, } \\
\text { COMBIN14 } \\
\text { MATRIX50 }\end{array}$ \\
\hline 2.6 & $\begin{array}{l}\text { "metal structures of the roof"+ } \\
\text { superelement of the reinforced } \\
\text { concrete construction } \\
\text { of foundations and stands }\end{array}$ & & 21651 & 14972 & $\begin{array}{l}\text { BEAM188 } \\
\text { LINK180 } \\
\text { SURF154 } \\
\text { MATRIX50 }\end{array}$ \\
\hline
\end{tabular}

A comparative analysis of the natural frequencies and mode shapes of the complete system "base reinforced concrete structures of foundations and stands - metal structures of the roof" and subsystems of the stadium in Nizhny Novgorod revealed a weak effect of the flexibility of the support subsystem on the dynamic characteristics of the coating structure subsystem, which allows us to justify study of the latter in a separate model. In turn, the subsystem "metal structures of the roof" does not have a significant effect on the behavior of the support subsystem "base - reinforced concrete construction of foundations and tribunes", which also gives reason to carry out studies of the isolated subsystem.

A similar comparison of the natural frequencies and mode shapes of the complete system and subsystems of the stadium in Rostov-on-Don showed a significant mutual influence of the reference subsystem and the subsystem of the coating structures on the dynamic characteristics. This indicates the impossibility of conducting independent calculations of subsystems without taking into account the stiffness and mass characteristics of all elements of the complete system.

In Tables 3 and 4, the natural frequency of the complete system and subsystems on which the mode shapes coincide are marked with a green background. The red background marks those frequencies of subsystems at which the mode shapes do not correspond to the mode shapes of the complete system or are absent. 
Superelement Simulation Technique of Dynamics for Large-Size System "Base - Reinforced Concrete Structures Metal Structures". Verification and Approbation

Table 3. Comparison of natural frequencies of the complete system and its constituent subsystems

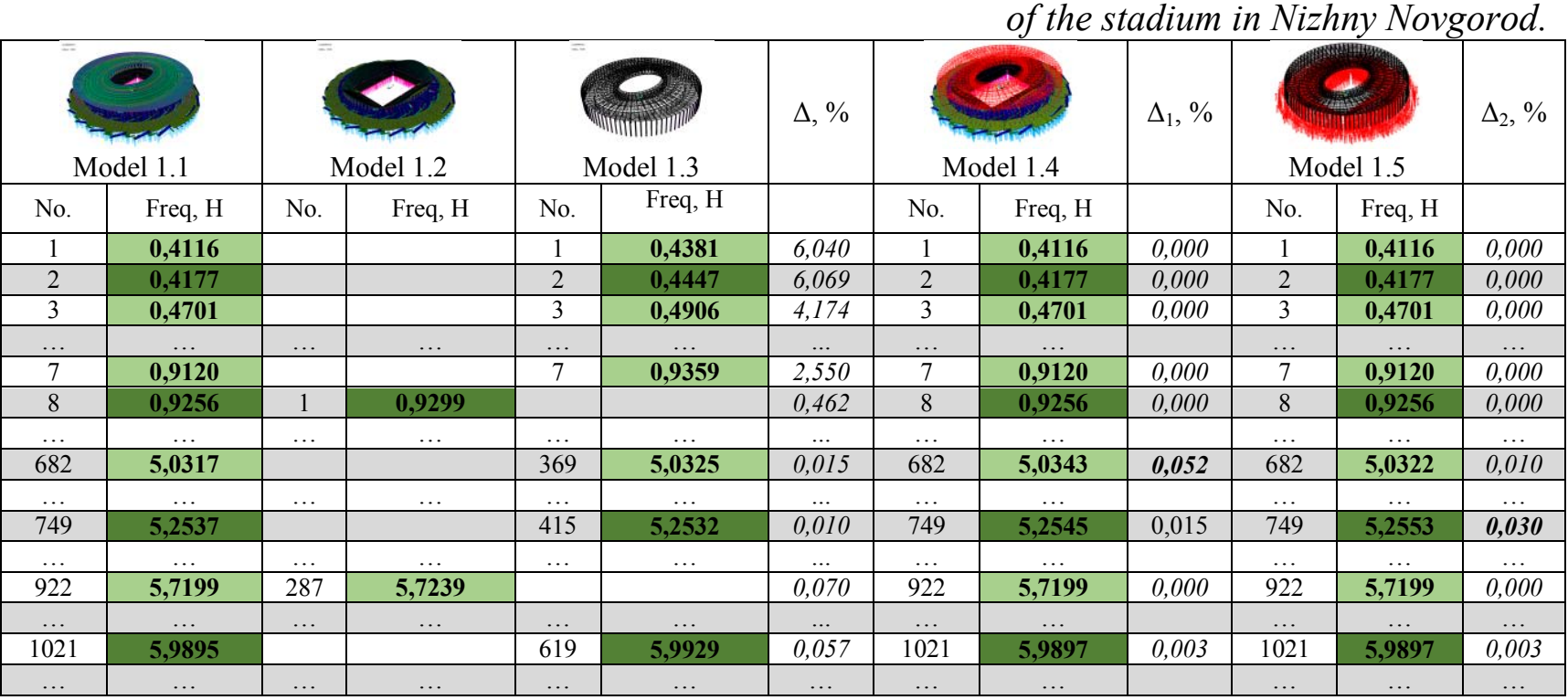

A comparison of the natural frequencies and mode shapes of complete systems and subsystems taking into account superelements shows that obtaining of dynamic characteristics using the component mode synthesis give results close to those when investigating the complete system. The discrepancy between the values of the obtained natural frequencies for most mode shapes does not exceed $0.050 \%$, and for individual modes, in the range under study, up to $0.900 \%$ depending on the frequency range considered, with a sufficient number of internal forms of vibration of the substructure taken into account.

Comparison of the dynamic characteristics, obtained by various versions of the component mode synthesis, allows us to formulate the following recommendations: for the formation of a superelement of the subsystem "base - reinforced concrete construction of foundations and tribunes", it is preferable to use the method of freedom boundaries, for the superelement of the subsystem "metal structures" - a fixed border method.

Table 4. Comparison of natural frequencies of the complete system and its constituent subsystems of the stadium in Rostov-on-Don.

\begin{tabular}{|c|c|c|c|c|c|c|c|c|c|c|c|c|c|c|}
\hline & del 2.1 & & del 2.2 & & el 2.3 & & 粨 & $\begin{array}{l}\circ \\
\triangleleft\end{array}$ & & el 2.5 & 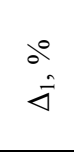 & & Iel 2.6 & $\begin{array}{l}\circ \\
\triangleleft\end{array}$ \\
\hline № & Freq, $\mathrm{Hz}$ & № & Freq, $\mathrm{H}$ & № & Freq, $\mathrm{H}$ & № & Freq, $\mathrm{H}$ & & № & Freq, H & & № & Freq, $\mathrm{H}$ & \\
\hline 1 & 1,2304 & & & & & 1 & 1,3157 & 6,483 & 1 & 1,2304 & 0,000 & 1 & 1,2323 & 0,154 \\
\hline 2 & 1,4093 & & & & & 2 & 1,4253 & 1,123 & 2 & 1,4093 & 0,000 & 2 & 1,4095 & 0,014 \\
\hline 3 & 1,5981 & & & & & 3 & 1,7469 & 8,518 & 3 & 1,5982 & 0,000 & 3 & 1,5987 & 0,031 \\
\hline 4 & 1,6012 & & & 1 & 1,7369 & & & 7,813 & 4 & 1,6013 & 0,000 & 4 & 1,6014 & 0,006 \\
\hline 5 & 1,6498 & 1 & 1,6504 & & & & & 0,036 & 5 & 1,6502 & 0,018 & 5 & 1,6501 & 0,024 \\
\hline 6 & 1,6658 & & & & & 4 & 1,8129 & 8,114 & 6 & 1,6660 & 0,006 & 6 & 1,6668 & 0,054 \\
\hline 7 & 1,7059 & & & 2 & 1,8215 & & & 6,346 & 7 & 1,7060 & 0,000 & 7 & 1,7068 & 0,047 \\
\hline 8 & 1,7275 & 2 & 1,7790 & & & & & & 8 & 1,7277 & 0,012 & 8 & 1,7339 & 0,369 \\
\hline & & & & & & & & & & & & & & \\
\hline 16 & 1,9766 & & 1,9773 & & & & & & 16 & 1,9773 & 0,035 & 16 & 1,9763 & 0,015 \\
\hline 93 & 3.0150 & & 3.0377 & & 3.0220 & & & & 93 & 3,0151 & 0,003 & 93 & 3,0381 & \\
\hline & & & & $\cdots$ & & & & $\ldots$ & & & & & & \\
\hline 350 & 5,9914 & & & & & & & & 350 & 5,9915 & 0,002 & 350 & 5,9915 & 0,002 \\
\hline & & & & & & & & & & & & & & \\
\hline
\end{tabular}




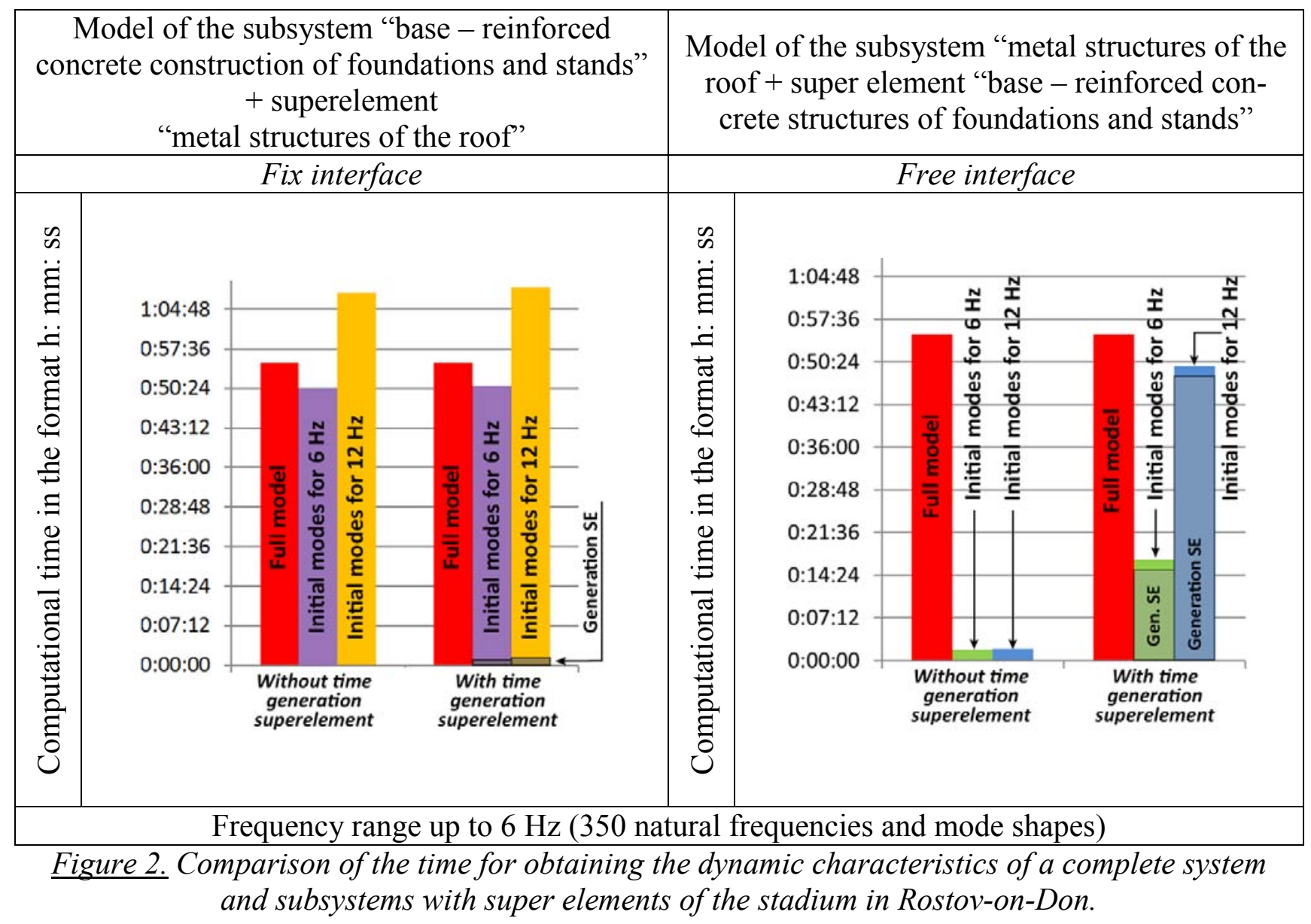

It is with this approach that the minimum discrepancy between the natural frequencies and mode shapes of the complete system and subsystems using superelements is achieved. Also, the recommendation was confirmed to hold for the substructure all mode shapes and natural frequencies of which are 1.5-2 times higher than the studied frequency range for the entire system $[9,10]$.

The total "machine" time for the formation of a superelement and obtain the dynamic characteristics of the subsystem with its application, taking into account a sufficient number of internal modes of the substructure, is comparable to the time spent on the investigation of the complete system. The time for investigation the subsystem "metal structures of the roof" taking into account the superelement "base - reinforced concrete structures" (not taking into account the spent "machine" time for the genegation of the superelement) is 15-30 times (for Rostov-on-
Don. Figure 2) and 40-75 times (for Nizhny Novgorod) less than that spent on the investigation of the complete system. This gives a significant gain in computational efficiency when conducting multivariate computational investigations of the subsystem "metal structures of the roof" in order to optimize it, since it is not necessary to re-generate the superelement.

\section{CONCLUSION}

Summarizing the results presented in this article, we can draw the following conclusions:

1) An effective superelement technique of numerical simulation of dynamic characteristics of largesized systems "base - reinforced concrete structures - metal structures of the roof" was developed, verified and approbated, which allows us to proceed to the investigation of subsystems "base", 
Superelement Simulation Technique of Dynamics for Large-Size System "Base - Reinforced Concrete Structures Metal Structures". Verification and Approbation

"reinforced concrete structures" and "metal structures of the roof" as part of individual models.

2) Verification examples (including the entrance block of the Volgamall shopping center in Volzhsky) demonstrated the effectiveness and features of using the developed superelement technique to investigate the dynamic characteristics of combined systems of a similar type.

3) A comparative analysis of the natural frequencies and mode shapes of the complete system and subsystems of the stadium in Nizhny Novgorod revealed a weak effect of the compliance of the support subsystem on the dynamic characteristics of the coating structures, which allows us to justify the investigate of the latter within a separate model. In turn, the subsystem of coating structures does not significantly affect the behavior of the supporting subsystem, which also gives reason to perform its investigations in isolation.

4) On the contrary, a comparison of the natural frequencies and mode shapes of the complete system and the structural subsystems of the stadium in Rostov-on-Don showed a significant mutual influence of the subsystems on the dynamic characteristics. This indicates the impossibility of investigating subsystems for individual models without the use of superelements.

5) Analysis of natural frequencies and mode shapes of complete systems and subsystems with superelements of stadiums in Nizhny Novgorod and Rostov-on-Don show that the dynamic characteristics are almost identical when taking into account a sufficient number of internal natural frequencies and mode shapes of substructures.

6) The most valuable, "organizational" effectiveness of the developed technique for two real combined large-sized systems "foundation reinforced concrete construction of foundations and stands - metal structures of the roof" with the use of superelement approaches was demonstrated. The computational competitiveness of the developed models with superelements was confirmed (compared to the full FE models).

7) The presented results allow us to recommend the developed superelemental technique for use for a wide class of computational investigations of combined large-sized systems of unique buildings and structures.

8) The development and application of the proposed superelement technique of numerical simulation of combined large-sized systems to solve problems in physical, geometrical, structural and genetically non-linear settings seems to be a prospect for further development of this topic.

\section{REFERENCES}

1. Gayan R. Privedenie Matric Zhestkosti I Massy [The Reduction of the Stiffness and Mass Matrices]. // Raketnaya Tekhnika I Kosmonavtika, 1965, Volume 3, Number 2, pp. 277-278 (in Russian).

2. Craig R.R.,Jr., Bampton M.C.C. Coupling of substructures for dynamic analysis. // AIAA Journal, 1968, Volume 6, No. 7, pp. 1313-1319.

3. Hurty W.C. Dynamic analysis of structural systems using component modes. // AIAA Journal, 1984, Volume 4, pp. 733-738.

4. Zu-Qing Qu. Model Order Reduction Techniques with Applications in Finite Element Analysis. Springer Publications, 2004 (Electronic book; ISBN 978-1-4471-3827-3).

5. Craig R., Chang C.-J. Free-interface methods of substructure coupling for dynamic analysis. // AIAA Journal, 1976, Volume 14, No. 11, pp. 1633-1635.

6. MacNeal R.H. A hybrid method of component mode synthesis. // Computers and structures, 1971, Volume 4, pp. 591-601.

7. Curnier A. On three modal synthesis variants. // Journal of Sound and Vibration, 1983, Volume 90, No. 4. pp. 527-540.

8. Nagibovich A.I. Metodika superelementnogo modelirovaniya dinamiki sistem "osnovaniye - konstruktsii fundamentov i tribun - kon-struktsii pokrytiya" stadionov chempionata mira po futbolu 2018 goda $\mathrm{v}$ Rossii. Opisaniye i verifikatsiya. // International Journal for Computational Civil and Structural Engineering, 2018, Volume 14, Issue 2, pp. 117-132 (in Russian). 
9. Nagibovich A.I. Superelementnoye modelirovaniye dinamicheskikh kharakteristik bol'sherazmernykh kombinirovannykh sistem «osnovaniye - zhelezobetonnyye konstruktsii - metallicheskiye konstruktsii»// Dissertation of the Candidate Technical Sciences. Moscow, 2019, 161 pages.

10. Rubin S. Improved component-mode representation for structural dynamic analysis. // AIAA Journal, 1975, Volume 13, No. 8, pp. 995-1006.

11. Nagibovich A.I. Approbation of the developed technique of superelement simulation of dynamics for system "Basis-Foundations structures and stands - Structures of the roof" for stadiums for the 2018 FIFA World Cup in Russia. // IOP Conference Series: Materials Science and Engineering, 2018, Volume 456, 012121.

\section{СПИСОК ЛИТЕРАТУРЫ}

1. Гайан Р. Приведение матрицы жесткости и массы. // Ракетная техника и космонавтика, 1965, Том 3, № 2, с. 277-278.

2. Craig R.R.,Jr., Bampton M.C.C. Coupling of substructures for dynamic analysis. // AIAA Journal, 1968, Volume 6, No. 7, pp. 1313-1319.

3. Hurty W.C. Dynamic analysis of structural systems using component modes. // AIAA Journal, 1984, Volume 4, pp. 733-738.

4. Zu-Qing Qu. Model Order Reduction Techniques with Applications in Finite Element Analysis. Springer Publications, 2004 (Electronic book; ISBN 978-1-4471-3827-3).

5. Craig R., Chang C.-J. Free-interface methods of substructure coupling for dynamic analysis. // AIAA Journal, 1976, Volume 14, No. 11, pp. 1633-1635.

6. MacNeal R.H. A hybrid method of component mode synthesis. // Computers and structures, 1971, Volume 4, pp. 591-601.

7. Curnier A. On three modal synthesis variants. // Journal of Sound and Vibration, 1983, Volume 90, No. 4. pp. 527-540.
8. Nagibovich A.I. Metodika superelementnogo modelirovaniya dinamiki sistem "osnovaniye - konstruktsii fundamentov $\mathrm{i}$ tribun - kon-struktsii pokrytiya" stadionov chempionata mira po futbolu 2018 goda $\mathrm{v}$ Rossii. Opisaniye i verifikatsiya. // International Journal for Computational Civil and Structural Engineering, 2018, Volume 14, Issue 2, pp. 117-132.

9. Нагибович А.И. Суперэлементное моделирование динамических характеристик большеразмерных комбинированных систем «основание - железобетонные конструкции - металлические конструкции». Диссертация на соискание ученой степени кандидата технических наук по специальности 05.13.18 - «Математическое моделирование, численные методы и комплексы программ». - М.: НИУ МГСУ, 2019. - 161 с.

10. Rubin S. Improved component-mode representation for structural dynamic analysis. // AIAA Journal, 1975, Volume 13, No. 8, pp. 995-1006.

11. Nagibovich A.I. Approbation of the developed technique of superelement simulation of dynamics for system "Basis-Foundations structures and stands - Structures of the roof' for stadiums for the 2018 FIFA World Cup in Russia. // IOP Conference Series: Materials Science and Engineering, 2018, Volume 456, 012121.

Alexander I. Nagibovich, Senior Engineer of Scientific Research Center "StaDyO"; University teacher, Department of Applied Mathematics, National Research Moscow State University of Civil Engineering; office 810, 18, 3ya Ulitsa Yamskogo Polya, Moscow, 125040, Russia; phone +7 (499) 706-88-10;

E-mail: nagibovich@yandex.ru.

Нагибович Александр Игоревич, ведущий инженеррасчетчик, ЗАО «Научно-исследовательский центр СтаДиО»; преподаватель кафедры прикладной математики, Национальный исследовательский Московский государственный строительный университет; 125040, Москва, ул. 3-я Ямского Поля, д.18, офис 810; тел. 7 (499) 706-88-10; e-mail: nagibovich@yandex.ru. 